\title{
THE PATTERN OF LAND UTILIZATION IN LEH DISTRICT
}

1985 TO 2015

\section{DEACHEN CHOROL \& SANJEEV SHARMA}

Research Scholar, Department of Geography, University of Jammu, Jammu and Kashmir, India

\begin{abstract}
With ever increasing studies on the resources available to mankind, studies on land in general and land utilization pattern in particular is no exception. The study deals with analysis regarding the evolution of the land use pattern in the district of Leh in Jammu and Kashmir State from 1985 to 2015. Percentage share of each land use, the relative changes and correlation between the classes were focussed on. The findings has it straight that on an average major land use classes such as Area not available for cultivable (63.62\%) has the maximum share in the total reporting area all through 1985 to 2015, and contrary to this Fallow land (1.05\%) has the minimum average share to the reporting area. The studies on percentage of the total reporting area reveals that amongst all Barren and uncultivable land (60.8\%) use class has the maximum share of land in the year 2015.
\end{abstract}

KEYWORDS: Land Utilization Pattern, Leh, PRA-Percentage to Total Reporting Area \& LAHDC-Ladakh Autonomous Hill Development Council

Received: May 07, 2019; Accepted: May 28, 2019; Published: Jun 14, 2019; Paper Id.: IJHRMRAUG20192

\section{INTRODUCTION}

Land is the most essential natural resource on which all human activities are based (National Land Use and Conservation Board, 1988). Many studies have shown that there remain only few landscapes on the earth those are still in their natural state (David, 1968). As in all other countries of the world, land in India is put to various uses. Land utilization in simple terms is distribution of the total geographical area under various uses (Manhas and Jasrotia, 2013). Land utilization is the use made of land by a human, as surveyed and mapped in a series of recognized categories. The primary use of the land is for crops, forest, pasture, mining, transportation, gardening, residential, recreational, industrial, commercial and uncultivated waste, barren and fallow land etc. The difference between land use and land utilization is important. Land use is the use actually made of any parcel of land, House, apartments and industrial location are land use categories, whereas the term residential, industrial and agricultural refers to a system of land utilization implying roads, neighbourhood retail and service activities as well as location of industries, and the carrying of agricultural pursuits. In a rural area, tree crop or row crop would identify land use, whereas orcharding, truck farming and grazing indicate a system of land utilization. The study of land utilization has economic, geographic and demographic dimensions. The utilization of the land depends upon various physical and human factors like terrain, soil, climate, population density, occupation and technological advancement of the people (Mandal,1990). The information on the land use provided by the statistical Handbook of Leh relies on 9 fold Land use classification system proposed by the Directorate of economics and statistics, Government of India. And here it's being loosely enclosed in seven classes, like Land put to non agricultural use, Barren and uncultivable land, Land under misc trees and grooves, Cultivable wasteland, Fallow land other than current fallow, Current fallow and 
Net sown area. These classes are studied under as a part of the major heads such as; Area not available for cultivation, Cultivable waste land excluding fallow, Fallow land and Net area sown. Two land use categories namely; Forest and another Permanent pastures and other grazing land which falls under Cultivable wasteland excluding fallow is excluded from the analysis as there is no data available on them from the area of interest. The data has been slightly corrected and modified taking into consideration the best needed calculation before being finally analyzed upon. This includes correcting the figures of reporting area by the addition and in some case subtraction of the obvious figures of land use classes.

\section{STUDY AREA}

Leh is situated between the graticule of 32 to $36 \mathrm{~N}$ latitude and 75 to $80 \mathrm{E}$ longitude. Almost whole of the district is mountainous with three parallel ranges namely; Zangskar Range, Ladakh Range and Karakoram Range. Ladakh region lies on the rain shadow side of the Himalayan mountain range, thus the famous Indian monsoon contributing nothing to the area. The region is often mentioned a 'Cold Desert' considering the arctic and desert type of climate. Leh district if flanked in the east by Tibet (China), west by the District of Kargil, in the north by mainland China and south by the Indian state of Himachal Pradesh. Leh as a district was carved out of Ladakh region in July 1979. It comprises of 6 Sub divisions; namely Leh, Khaltse, Nubra, Kharu, Nyoma, Durbuk and Likir, 8 Tehsils, 16 Blocks, 112 inhabited and 1 un-inhabited villages.

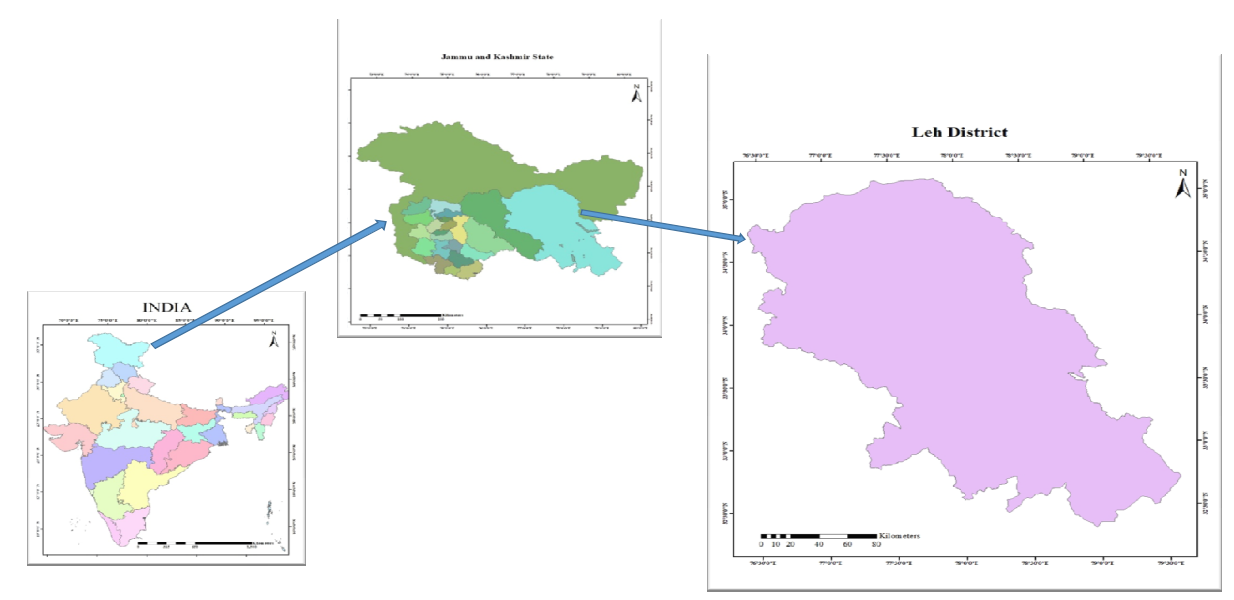

Figure 1: Location Map of the Study Area

\section{OBJECTIVES OF THE STUDY}

- To study the share of area under different land use categories in Leh district from 1985 to 2015.

- To analyze the trend of the Land utilization pattern in Leh district from 1985 to 2015.

\section{DATA SOURCES AND METHODOLOGY}

\section{Materials}

The study is based on secondary data by the District Statistical Handbook of Leh published by Directorate of Economics and Statistics, Govt. of Jammu and Kashmir.

\section{Methods}

- Percentage to the total reporting area is calculated as; (Computed by the author) 
$P R A=\frac{\text { Area of each land use }}{\text { Total reporting area }} \times 100$

- Relative Change is calculated as;

Relative Change $=\frac{\text { Value of LULC in later year- Value of LULC in base year }}{\text { Value of LULC in base year }} \times 100$

- Karl Pearson coefficient of correlation

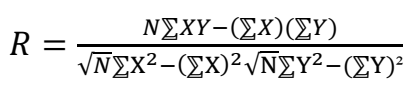

- Attempt is made toanalyze, correlate and interpretthe trends in the available data by applying suitable statistical and graphical representation.

\section{RESULTS AND DISCUSSIONS}

A Reporting area is an area for which data on land use classification is available. In areas where land utilization figures are based on land records, reporting area is the area in line with the village papers. These are generally the papers prepared by the village accountants or patwaris. In some cases, the village papers might not be maintained in respect of the entire area of the State concerned. For example, village papers are not prepared for the forest areas. Additionally there are tracts in many States for which no village paper exists. In such cases, ad-hoc estimates of classification of area are derived to finish the coverage.

Table 1: Land Utilization Pattern (In Hectares)

\begin{tabular}{|c|c|c|c|c|c|c|c|c|c|}
\hline Year & $\begin{array}{c}\text { Reporting } \\
\text { Area }\end{array}$ & $\begin{array}{c}\text { Area not } \\
\text { Available for } \\
\text { Cultivation }\end{array}$ & PRA & $\begin{array}{c}\text { Cultivable } \\
\text { Wasteland } \\
\text { Excluding Fallow }\end{array}$ & PRA & $\begin{array}{c}\text { Fallow } \\
\text { Land }\end{array}$ & PRA & $\begin{array}{c}\text { Net } \\
\text { Area } \\
\text { Sown }\end{array}$ & PRA \\
\hline 1985 & 44479 & 26789 & 60.2 & 7275 & 16.3 & 669 & 1.5 & 9746 & 21.9 \\
\hline 1990 & 45167 & 28135 & 62.3 & 6643 & 14.7 & 514 & 1.1 & 9875 & 21.9 \\
\hline 1995 & 45167 & 28070 & 62.1 & 6602 & 14.6 & 557 & 1.2 & 9938 & 22.0 \\
\hline 2000 & 45167 & 28071 & 62.1 & 5554 & 12.3 & 398 & 0.9 & 11144 & 24.7 \\
\hline 2005 & 51347 & 33586 & 65.4 & 7117 & 13.9 & 458 & 0.9 & 10186 & 19.8 \\
\hline 2010 & 51975 & 34242 & 65.9 & 7119 & 13.7 & 417 & 0.8 & 10197 & 19.6 \\
\hline 2015 & 45146 & 30452 & 67.4 & 4299 & 9.5 & 471 & 1.0 & 9924 & 22.0 \\
\hline
\end{tabular}

Source: Statistical Handbook 1985-2015, LAHDC-Leh

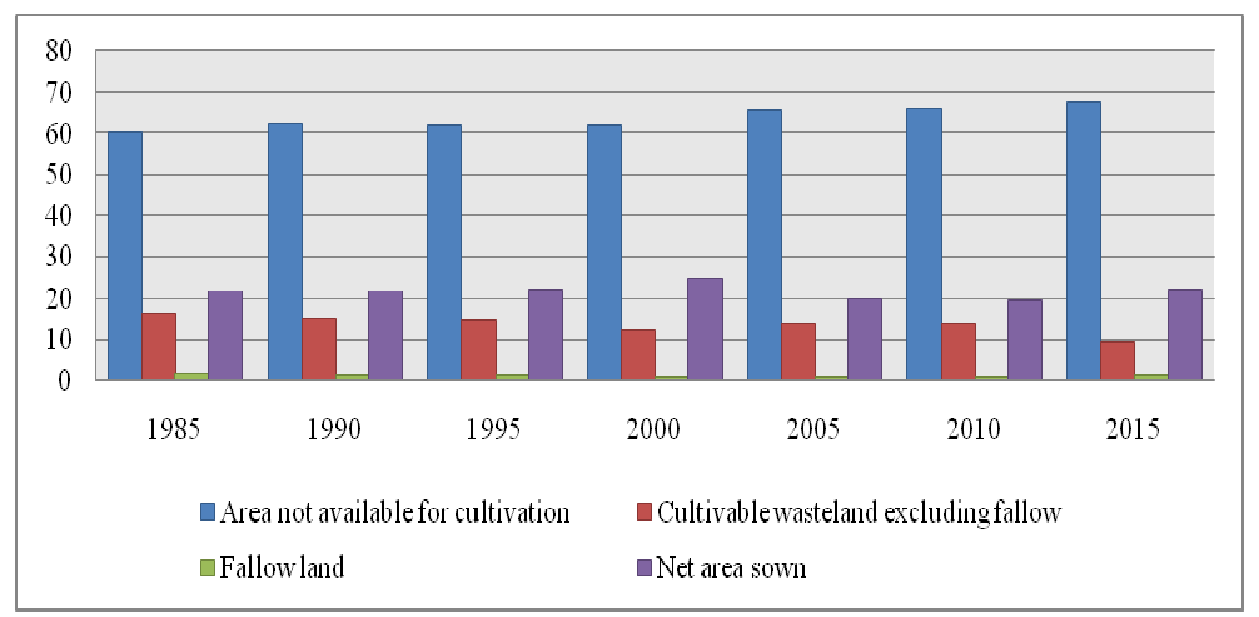

Figure 2: Land Utilization Pattern and PRA 


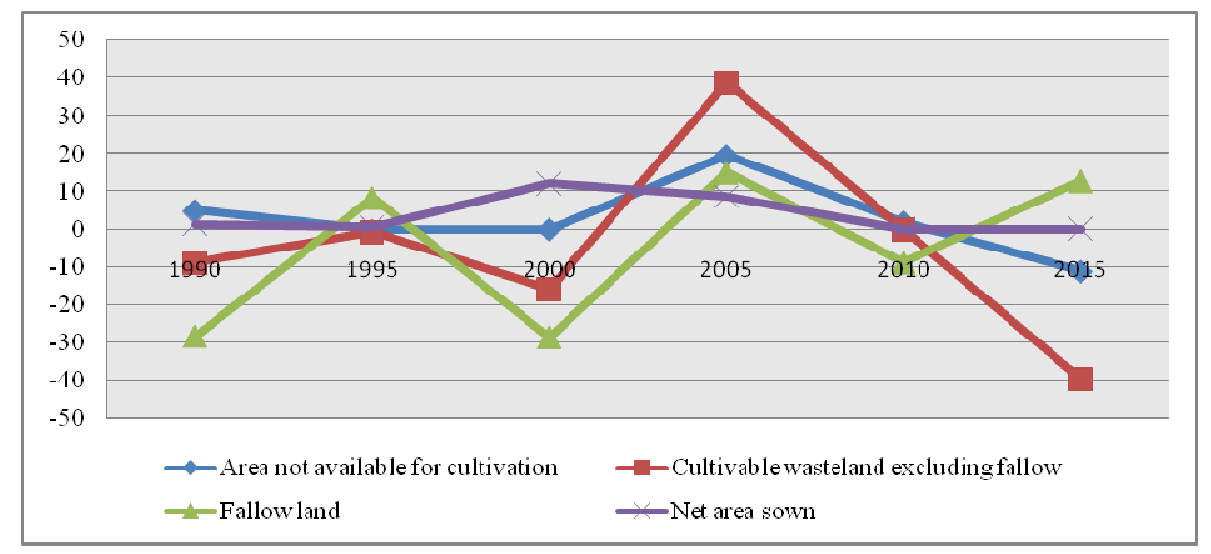

Figure 3: Relative Change of Land Utilization Pattern in Percentage

The above table deals with the PRA and relative change regarding Land utilization pattern of the Leh district. The overall maximum share of the land use class to the reporting area all through these decades was by Area not available for cultivation (67.4\%) in 2015 and on the contrary the least share was witnessed in $2010(0.8 \%)$ by Fallow land. In individual cases each land use categories have maximum to minimum share to the total reporting area. Starting with Area not available for cultivation; the land use class has its maximum was in the year $2015(67.4 \%)$ and on the contrary the least share was witnessed in $1985(60.2 \%)$. The report further imply that on the one hand the maximum share of the land use class of Cultivable wasteland excluding fallow was (16.3\%) in 1985 and on the other the opposite was witnessed in 2015 $(9.5 \%)$.

While year 1985 depicts $1.5 \%$ as Fallow lands' maximum share to the total reporting area, 2010 has its minimum share of 0.8 to the same. It findings also shows in case of Net area sown that the maximum share of the land use class was in the year $2000(24.7 \%)$ and on the contrary the least share was witnessed in 2010 (19.6\%). On an average Area not available for cultivable (63.62\%) has the maximum share as land use class into the total reporting area all through 1985 to 2015, and contrary to this Fallow land $(1.05 \%)$ has the minimum average share to the reporting area.

\section{Area not Available for Cultivation}

The land use category of Area not available for cultivation includes Area under non agricultural uses and Barren and uncultivable land. Area under non agricultural use includes all land occupied by buildings, roads or underwater and all land put to non agriculture use. Barren and uncultivable land on the other hand consists of all land covered by mountains, deserts. Basically these are the land that cannot be brought under cultivation except at an excessive cost.

Table 2: Area not Available for Cultivation (In Hectares)

\begin{tabular}{|c|c|c|c|c|c|c|c|}
\hline Year & $\begin{array}{c}\text { Reporting } \\
\text { Area }\end{array}$ & $\begin{array}{c}\text { Land put to non } \\
\text { Agricultural use }\end{array}$ & PRA & $\begin{array}{c}\text { Relative } \\
\text { Change }\end{array}$ & $\begin{array}{c}\text { Barren and } \\
\text { Uncultivable } \\
\text { Land }\end{array}$ & PRA & $\begin{array}{c}\text { Relative } \\
\text { Change }\end{array}$ \\
\hline 1985 & 44479 & 1806 & 4.1 & - & 24983 & 56.2 & - \\
\hline 1990 & 45167 & 2280 & 5.0 & 26.2 & 25255 & 55.9 & 1.1 \\
\hline 1995 & 45167 & 2902 & 6.4 & 27.3 & 25168 & 55.7 & -0.3 \\
\hline 2000 & 45167 & 2908 & 6.4 & 0.2 & 25163 & 55.7 & 0.0 \\
\hline 2005 & 51347 & 7066 & 13.8 & 143.0 & 26520 & 51.6 & 5.4 \\
\hline 2010 & 51975 & 7073 & 13.6 & 0.1 & 27160 & 52.2 & 2.4 \\
\hline 2015 & 45146 & 2978 & 6.6 & -57.9 & 27474 & 60.8 & 1.1 \\
\hline
\end{tabular}

Source: Statistical Handbook 1985-2015, LAHDC-Leh 


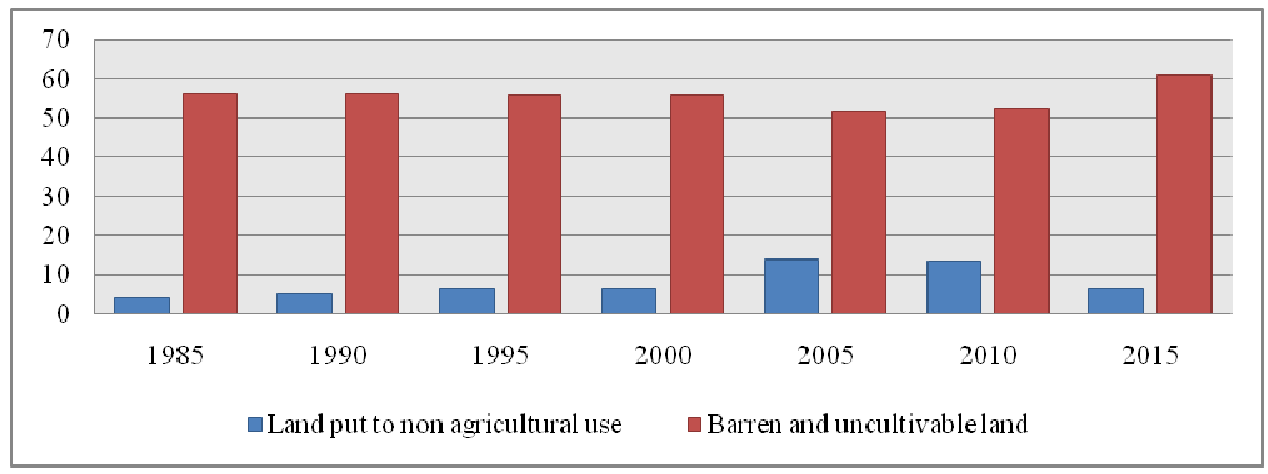

Figure 4: Area not Available for Cultivation and PRA

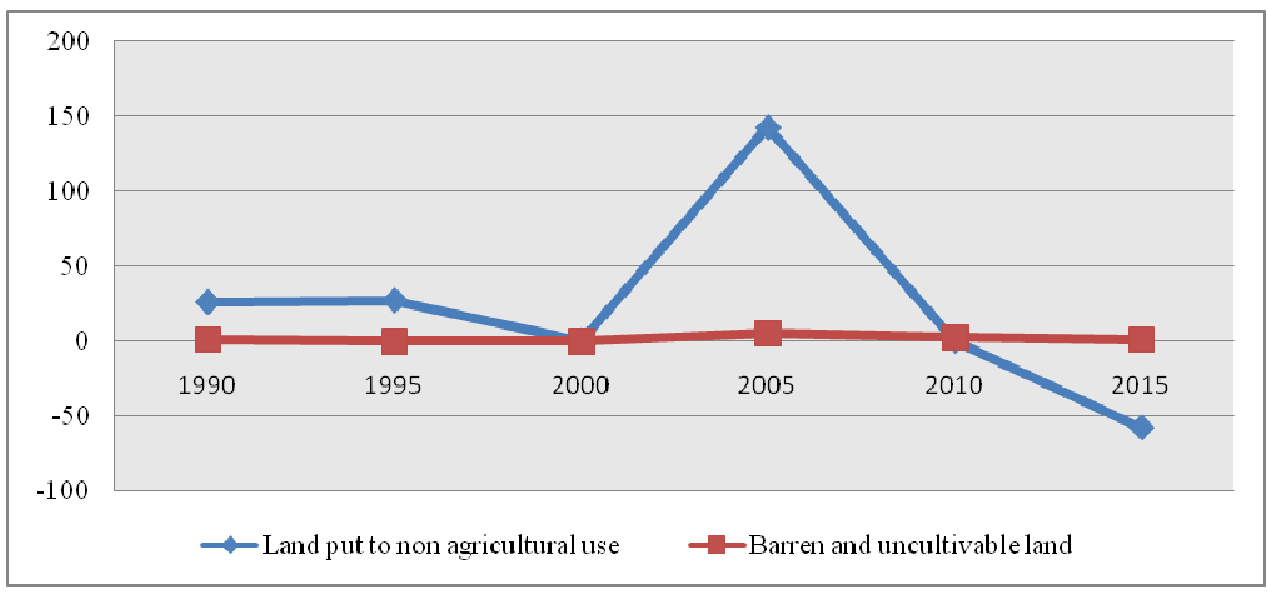

Figure 5: Relative Change of Area not Available for Cultivation in Percentage

The above table deals with the PRA and relative change regarding Area not available for cultivation. The PRA report suggest that the maximum share of the land use class of Land put to non agricultural use was in the year 2010 $(13.6 \%)$ and on the contrary the least share was witnessed in 1990 (5.0\%). The data on the relative change depicts a maximum rise of $142.8 \%$ in the share of Land put to non agricultural use between 2000 (0.2\%) and 2005 (143.0\%). Also, there was a fall of $58.0 \%$ between $2010(0.1 \%)$ and $2015(-57.9)$ in the same land use category.

According to the data on the other half of the table, the PRA data suggest that the maximum share of the land use class of Barren and uncultivable land to the total reporting area was in the year $2015(60.8 \%)$ and on the contrary the slightest share was witnessed in 2005 (51.6\%). The data on the relative change depicts a maximum though negligible rise of 5.4\% in the share of the same between $2000(0.0 \%)$ and $2005(5.4 \%)$. Also, there was a fall of only $3 \%$ between 2005 $(5.4 \%)$ and 2010 (2.4). The trend according to the analysis in case of Barren and uncultivable land is somewhat low and devoid of any significant change.

\section{Cultivable Wasteland Excluding Fallow}

Cultivable wasteland excluding fallow includes the land use category like Permanent pasture and other grazing land, Land under misc. trees and grooves and Cultivable wasteland. The first category mentioned above is not analysis since there was no separate information is available about them besides one year. Land under misc. trees and grooves comprises of land actually is used for cultivation but haven't included as a part of Net area sown. The land not included in Orchards and which is covered by trees, grasses, bamboos, bushes and grooves for fuelwood are classified under this 
category.

Cultivable wasteland excluding fallow comprises of land is cultivated once or can be cultivated if tried but haven't been cultivated since five successive years including current year due to any reason. They may be reachable or unreachable and could be covered in shrubs and jungles which may lie in an isolated block or within cultivated holdings.

Table 3: Cultivable Wasteland Excluding Fallow (In Hectares)

\begin{tabular}{|c|c|c|c|c|c|c|c|}
\hline Year & $\begin{array}{c}\text { Reporting } \\
\text { Area }\end{array}$ & $\begin{array}{c}\text { Land under Misc. } \\
\text { Trees and Grooves }\end{array}$ & PRA & $\begin{array}{c}\text { Relative } \\
\text { Change }\end{array}$ & $\begin{array}{c}\text { Cultivable } \\
\text { Wasteland }\end{array}$ & PRA & $\begin{array}{c}\text { Relative } \\
\text { Change }\end{array}$ \\
\hline 1985 & 44479 & 2859 & 6.4 & - & 4416 & 9.9 & - \\
\hline 1990 & 45167 & 2243 & 5.0 & -21.5 & 4400 & 9.7 & -0.4 \\
\hline 1995 & 45167 & 2196 & 4.9 & -2.1 & 4406 & 9.7 & 0.1 \\
\hline 2000 & 45167 & 1148 & 2.5 & -47.7 & 4406 & 9.7 & 0 \\
\hline 2005 & 51347 & 2652 & 5.2 & 131.0 & 4465 & 8.7 & 1.3 \\
\hline 2010 & 51975 & 2621 & 5.0 & -1.2 & 4498 & 8.6 & 0.7 \\
\hline 2015 & 45146 & 1732 & 3.8 & -33.9 & 2567 & 5.7 & -42.9 \\
\hline
\end{tabular}

Source: Statistical Handbook 1985-2015, LAHDC-Leh

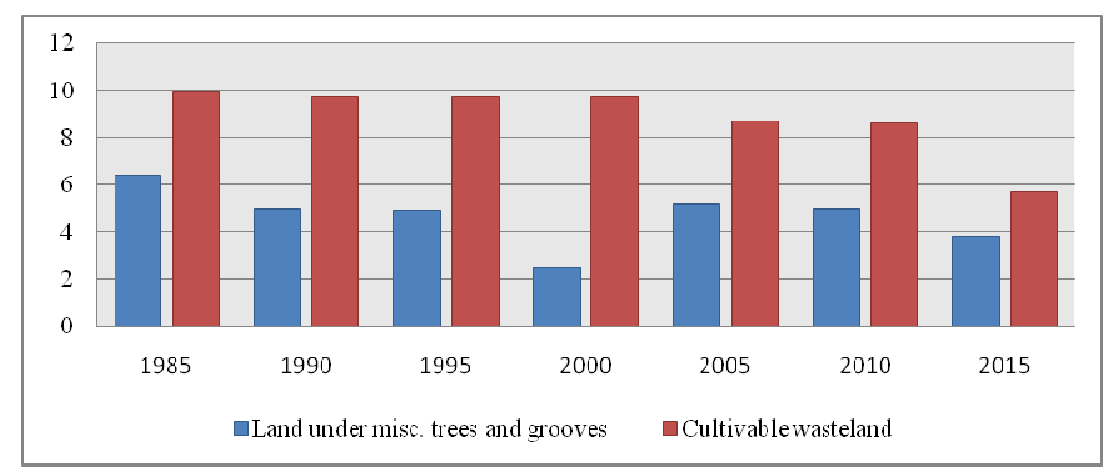

Figure 6: Cultivable Wasteland Excluding Fallow and PRA

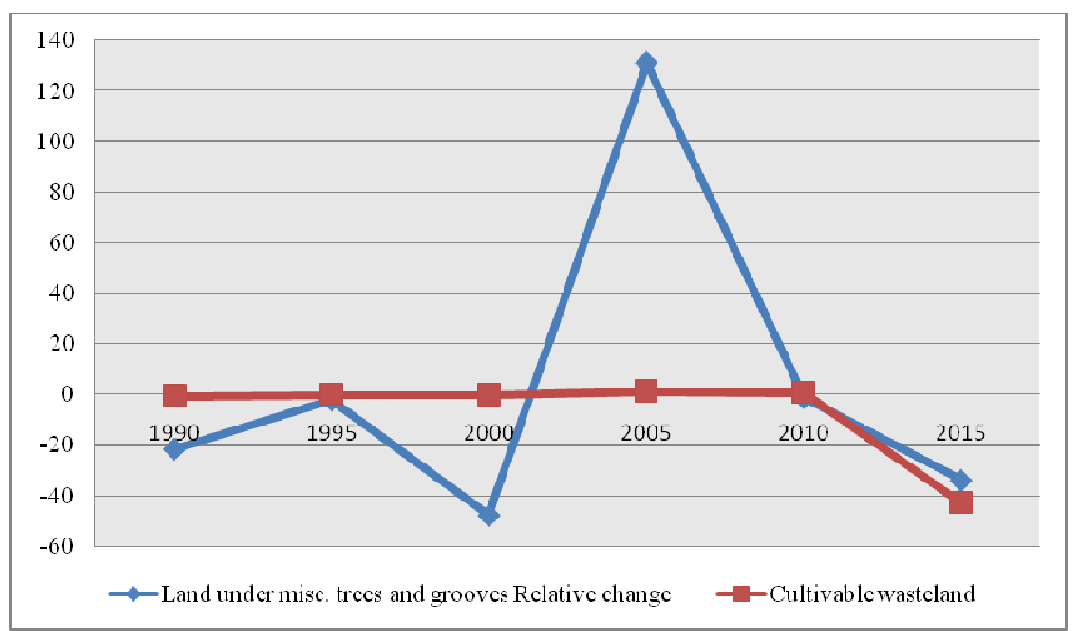

Figure 7: Relative Change of Cultivable Wasteland Excluding Fallow in Percentage

The above table deals with the PRA and relative change regarding Cultivable wasteland excluding fallow. The PRA suggest that the maximum share of the land use class of Land under misc. trees and grooves was in the year 1985 $(6.4 \%)$ and on the contrary the least share was witnessed in $2000(2.5 \%)$. The data on the relative change depicts a maximum rise of $178.7 \%$ in the share of Land under misc. trees and grooves between $2000(-47.7 \%)$ and 2005 (131.0\%). Also, there was a fall of $132.2 \%$ between $2005(131.0 \%)$ and $2010(-1.2)$ in the same. 
According to the data on the other half of the table, the PRA report suggest that the maximum share of the land use class of Cultivable wasteland was in the year 1985 (9.9\%) and on the contrary the least share was witnessed in 2015 $(5.7 \%)$. The data on the relative change depicts a maximum rise of only $0.5 \%$ in the share of Cultivable wasteland between $1990(-0.4 \%)$ and $1995(0.1 \%)$. Also there was a major fall of $43.6 \%$ between $2010(0.7 \%)$ and $2015(-42.9)$ in the same category.

\section{Fallow Land}

Fallow land as a whole comprises of Fallow land other than current fallow and Current fallow. Land use class of Fallow land other than current fallow includes all land which was once cultivated but is temporarily of cultivation for a continuous period of 2 to 5 years. Current fallow on the other hand represents the cropped area left uncultivated for a year.

Table 4: Fallow Land (In Hectares)

\begin{tabular}{|c|c|c|c|c|c|c|c|}
\hline Year & $\begin{array}{c}\text { Reporting } \\
\text { Area }\end{array}$ & $\begin{array}{c}\text { Fallow Land } \\
\text { other than } \\
\text { Current Fallow }\end{array}$ & PRA & $\begin{array}{c}\text { Relative } \\
\text { Change }\end{array}$ & $\begin{array}{c}\text { Current } \\
\text { Fallow }\end{array}$ & PRA & $\begin{array}{c}\text { Relative } \\
\text { Change }\end{array}$ \\
\hline 1985 & 44479 & 106 & 0.2 & - & 563 & 1.3 & - \\
\hline 1990 & 45167 & - & - & - & 514 & 1.1 & -8.7 \\
\hline 1995 & 45167 & 88 & 0.2 & - & 469 & 1.0 & -8.7 \\
\hline 2000 & 45167 & 116 & 0.2 & 31.8 & 282 & 0.6 & -39.9 \\
\hline 2005 & 51347 & 61 & 0.1 & -47.4 & 397 & 0.7 & 40.8 \\
\hline 2010 & 51975 & 59 & 0.1 & -3.3 & 358 & 0.7 & -9.8 \\
\hline 2015 & 45146 & 32 & 0.1 & -45.8 & 439 & 1.0 & 22.6 \\
\hline
\end{tabular}

Source: Statistical Handbook 1985-2015, LAHDC-Leh

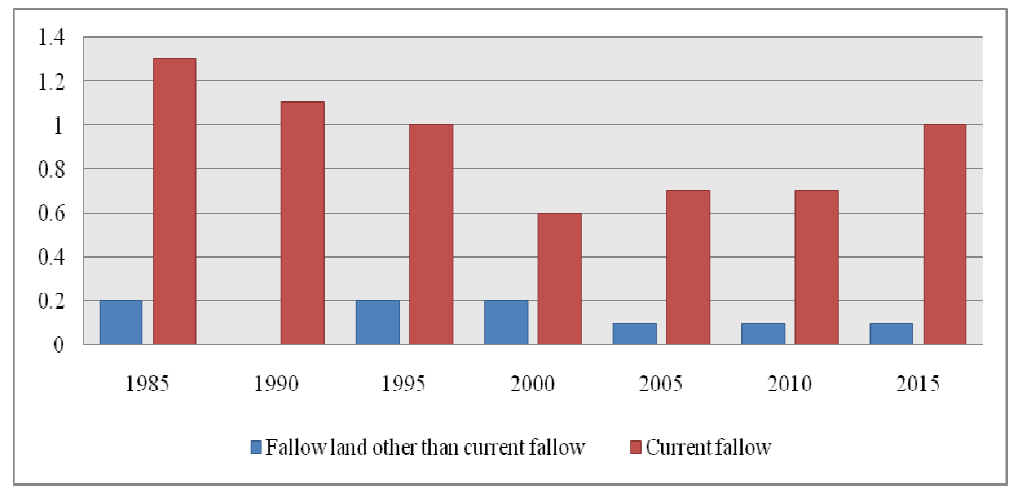

Figure 8: Fallow Land and PRA

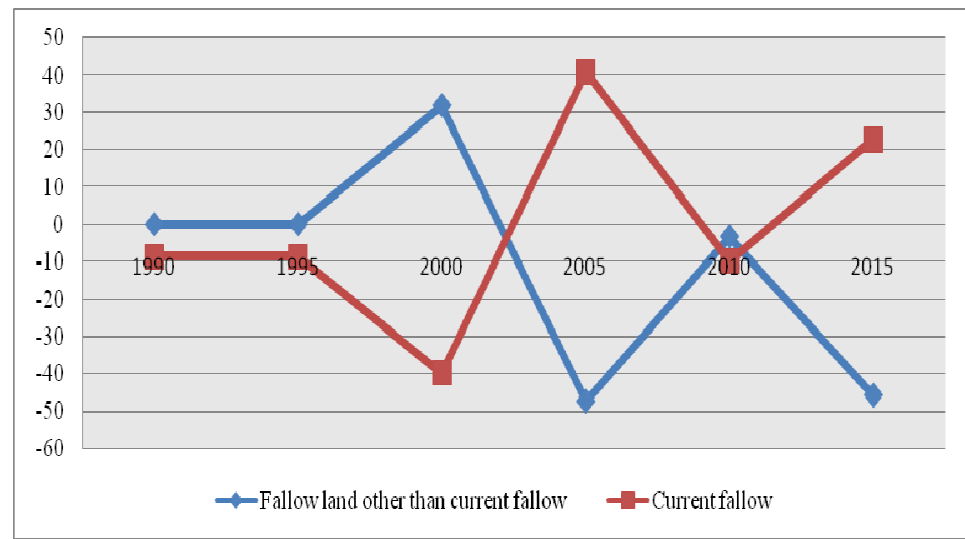

Figure 9: Relative Change of Fallow Land in Percentage 
The above table deals with the PRA and relative change regarding Fallow land. The PRA data suggest that the maximum share of the land use class of Fallow land other than current fallow $(0.2 \%)$ remained for three years of 1985 , 1995 and 2000 and on the contrary the least share was witnessed in the following years of 2005-2015 (0.1\%). The data on the relative change depicts two major fall in the share of the land use category; first being a drop of $79.2 \%$ between 2000 $(31.8 \%)$ and $2005(-47.4 \%)$ and the second drop of $42.5 \%$ was between $2010(-3.31 \%)$ and $2015(-45.8 \%)$.

According to the data on the other half of the table, the PRA report suggest that the maximum share of the land use class of Current fallow was in the year 1985 (1.3\%) and on the contrary the least share was witnessed in $2000(0.6 \%)$. The data on the relative change depicts a maximum rise of $80.7 \%$ in the share of Current fallowbetween $2000(-39.9 \%)$ ) and $2010(40.8 \%)$. Also, there was a fall of 31.2\% between $1995(-8.7 \%)$ and $2000(-39.9 \%)$ in the same. There is almost an opposite relationship between the two land use categories as; increase in the share of former is coupled with decrease of the later (1995-2000) and vice versa in 2000-2001 and 2010-2015.

Table 5: Correlation between Cultivable Wasteland and Fallow Land

\begin{tabular}{|c|c|c|c|c|}
\hline $\begin{array}{c}\text { Cultivable } \\
\text { Wasteland } \\
\mathbf{X}\end{array}$ & $\begin{array}{c}\text { Fallow Land } \\
\mathbf{Y}\end{array}$ & $\mathbf{X}^{\mathbf{2}}$ & $\mathbf{Y}^{\mathbf{2}}$ & $\mathbf{X Y}$ \\
\hline 7275 & 669 & 52925625 & 447561 & 4866975 \\
\hline 6643 & 514 & 44129449 & 264196 & 34141502 \\
\hline 6602 & 557 & 43586404 & 310249 & 3677314 \\
\hline 5554 & 398 & 30846916 & 158404 & 2210492 \\
\hline 7117 & 458 & 50651689 & 209764 & 3259586 \\
\hline 7119 & 417 & 50680161 & 1733884 & 2968623 \\
\hline 4299 & 471 & 18481401 & 221841 & 2024829 \\
\hline$\square \mathrm{X}$ & $\square \mathrm{Y}$ & $\square \mathrm{X}^{2}$ & $\square \mathrm{Y}^{2}$ & $\square \mathrm{XY}$ \\
44609 & 3484 & 291301645 & 1785899 & 22422321 \\
\hline
\end{tabular}

Source: Computed from the data above $\mathrm{R}=0.36$

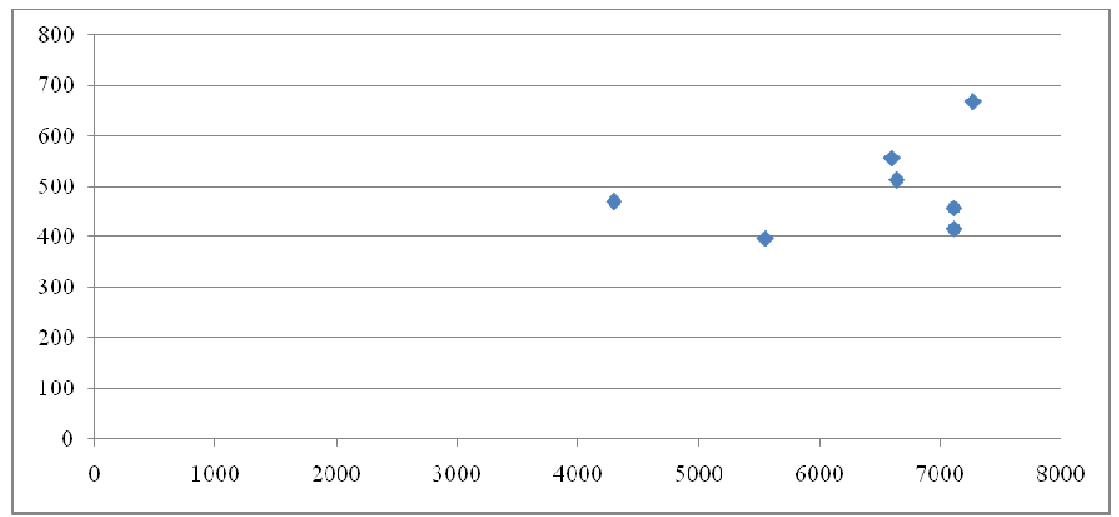

Figure 10: Scatter Diagram Depicts Correlation between Cultivable Wasteland and Fallow Land

The above data deals with correlation between Land usescategories namely; Cultivable wasteland and Fallow land. A perusal of the available data reveals that there is weal positive correlation (0.36), which means there is a negligible tendency of high X variable scores to go with high Y scores and vice versa. The Thus the correlation between Cultivable wasteland and Fallow land is positive and the magnitude of the correlation is 0.36. There has been an identical relation between the two therefore; any increase in one will lead to increase in another. The increase in Cultivable wasteland would lead to increase in Fallow land. 


\section{Net Area Sown}

Net area sown represents the total land area on which crops are grown once is a year. The Net sown area and the area sown more than once a year, together makes gross cultivated area.

Table 6: Net Area Sown (In Hectares)

\begin{tabular}{|c|c|c|c|c|}
\hline Year & $\begin{array}{c}\text { Reporting } \\
\text { Area }\end{array}$ & $\begin{array}{c}\text { Net Area } \\
\text { Sown }\end{array}$ & PRA & $\begin{array}{c}\text { Relative } \\
\text { Change }\end{array}$ \\
\hline 1985 & 44479 & 9746 & 21.9 & - \\
\hline 1990 & 45167 & 9875 & 21.9 & 1.3 \\
\hline 1995 & 45167 & 9938 & 22.0 & 0.6 \\
\hline 2000 & 45167 & 11144 & 24.7 & 12.1 \\
\hline 2005 & 51347 & 10186 & 19.8 & -8.6 \\
\hline 2010 & 51975 & 10197 & 19.6 & 0.1 \\
\hline 2015 & 45146 & 9924 & 22.0 & -2.7 \\
\hline
\end{tabular}

Source: Statistical Handbook 1985-2015, LAHDC-Leh

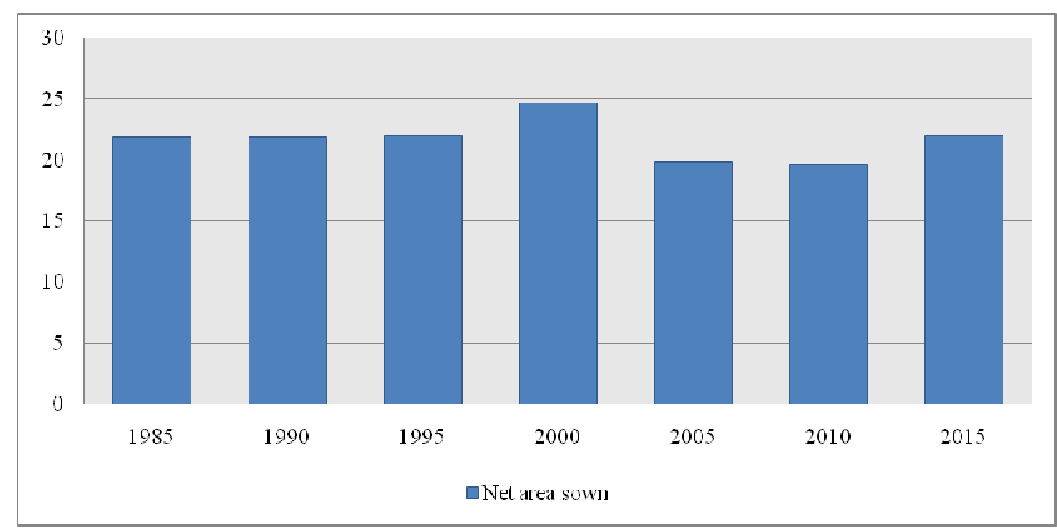

Figure 11: Net Area and PRA

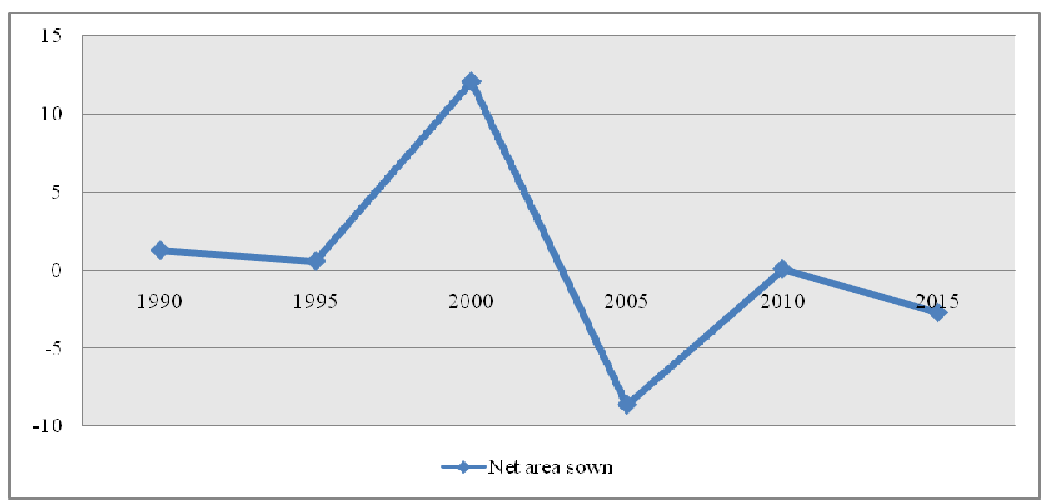

Figure 12: Relative Change of Net Area Sown in Percentage

The above table deals with the PRA and relative change regarding Net area sown. The PRA findings suggest that the maximum share of the land use class of Net area sown was in the year $2000(24.7 \%)$ and on the contrary the least share was witnessed in $2010(0.1 \%)$. The data on the relative change depicts a maximum rise of $11.5 \%$ in the share of Net area sown between $1995(0.6 \%)$ and $2000(12.1 \%)$. Also, there was a fall of 20.7\% between $2000(12.1 \%)$ and $2005(-8.6 \%)$ in the same. 
Table 7: Correlation between Fallow Land and Net Area Sown

\begin{tabular}{|c|c|c|c|c|}
\hline $\begin{array}{c}\text { Fallow Land } \\
\mathbf{X}\end{array}$ & $\begin{array}{c}\text { Net Area Sown } \\
\mathbf{Y}\end{array}$ & $\mathbf{X}^{\mathbf{2}}$ & $\mathbf{Y}^{\mathbf{2}}$ & $\mathbf{X Y}$ \\
\hline 669 & 9746 & 447561 & 94984516 & 6520074 \\
\hline 514 & 9875 & 264196 & 97515625 & 5075750 \\
\hline 557 & 9938 & 310249 & 98763844 & 5535466 \\
\hline 398 & 11144 & 158404 & 124188736 & 4435312 \\
\hline 458 & 10186 & 209764 & 103754596 & 4665188 \\
\hline 417 & 10197 & 1733884 & 103978809 & 4252149 \\
\hline 471 & 9924 & 221841 & 98485776 & 4674204 \\
\hline$\square \mathrm{X}$ & $\square \mathrm{Y}$ & $\square \mathrm{X}^{2}$ & $\square \mathrm{Y}^{2}$ & $\square \mathrm{XY}$ \\
3484 & 71010 & 1785899 & 721671942 & 35158143 \\
\hline
\end{tabular}

Source: Computed from the data above $\mathrm{R}=-0.7$

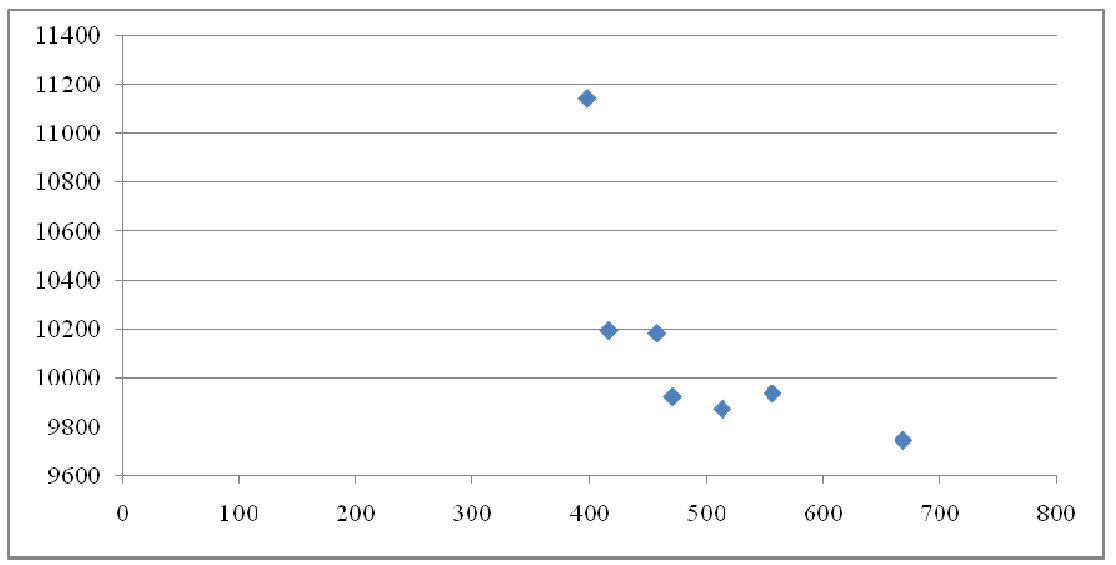

Figure 13: Scatter Diagram Depicts Correlation between Fallow Land and Net Area Sown

The above data deals with correlation between Land use classes namely; Fallow land and Net area sown. A perusal of the available data reveals that there is moderate negative correlation (-0.7), which means there is a tendency of high X variable scores to go with low Y scores and vice versa. The Thus the correlation between Fallow land and Net sown area is negative and the magnitude of the correlation is 0.7 . There has been an opposite relation between the two therefore; any increase in one will lead to decrease in another. The increase in Fallow land would lead to decrease in Net area sown.

\section{CONCLUSIONS}

The land use classification studied above as mentioned earlier is actually based on the 9 fold classification system proposed by the Directorate of economics and statistics, Government of India. The most significant observation in this regard is about the Reporting area. As per general perception the reporting area should and would grow with every passage of time but interestingly there have been many ups and downs in the graph of reporting area. For example the largest reporting area till date was 51975h (2010), whereas the smallest reporting area was 44479h (1985) and likewise, the average reporting area is $46921.1 \mathrm{~h}$. Considering the main land use categories such as; Area not available for cultivation, Cultivable wasteland excluding fallow, Fallow land and Net sown area, the data on the relative change of On one hand Area not available for cultivation depicts a maximum rise of 19.6\% between 2000 and 2005. On the other hand, a fall of 13\% was witnessed between $2010(1.9 \%)$ and $2015(-11.1 \%)$ in the same. The data on the relative change depicts a maximum rise of $54.7 \%$ in the share of Cultivable wasteland excluding fallow between $2000(-15.8 \%)$ and 2005 (38.9\%). 
Also, there was a maximum fall of $39.6 \%$ between $2010(0 \%)$ and 2015 (-39.6\%). Likewise, it depicts a maximum rise of $44 \%$ in Fallow land between $2000(-28.5 \%)$ and 2005 (15.1\%). There was also a maximum fall of $36.9 \%$ between 1995 $(8.4 \%)$ and $2000(-28.5 \%)$. Lastly, the data on the relative change portrays a maximum rise of $11.5 \%$ in the share of Net area sown between $1995(0.6 \%)$ and 2000 (12.1\%). Also, there was a fall of 20.7\% between $2000(12.1 \%)$ and $2005(-$ $8.6 \%$ ) in the same. The study does not notice any particular trend or pattern in the land use categories. Except Cultivable wasteland and Barren and uncultivable land, all the other land use classes were very unpredictable. Any expansion in their share is found to be soon followed by the contraction, that too on a big margin.

\section{REFERENCES}

1. Block wise Village Amenity Directory (2014-15). District Statistics \& Evaluation Office, Leh

2. David, L.S. (Ed). (1968). International Encyclopaedia of the Social Sciences. New York: The macamallion company and the free press. Vol. 8. pp 550

3. District Census Handbook, LehLadakh(2011).Directorate of Census Operations Jammu \& Kashmir; Series O2 Part XII-B

4. Mandal, R.B. (1990). Land utilization: Theory and Practice. Concept Publishing Company: New Delhi

5. Manhas, M.S and Jasrotia R. (2013). Systematic Geography of Jammu and Kashmir. Commonwealth Publishers Pvt. Ltd: New Delhi.

6. Nyandoro, Z. F., \& Goremusandu, T. Employees'evaluation of the Relationship between Reward Management and Organisational Strategy: A Case Study of Zimbabwe National Family Planning Council (ZNFPC).

7. National Land Use and Conservation Board, (1988). Ministry of Agriculture and Rural Development, Department of Agriculture and Co-peration, New Delhi 
